Article

\title{
Illustration of the Effects of Five Fungi on Acacia saligna Wood Organic Acids and Ultrastructure Alterations in Wood Cell Walls by HPLC and TEM Examinations
}

\author{
Maisa M. A. Mansour ${ }^{1}$, Safa Abd El-Kader Mohamed Hamed ${ }^{1}\left(\mathbb{C}\right.$, Mohamed Z. M. Salem ${ }^{2, *(1)}$ \\ and Hayssam M. Ali ${ }^{3,4}$ \\ 1 Conservation Department, Faculty of Archaeology, Cairo University, Giza 12613, Egypt; \\ maisamansour_40@yahoo.com (M.M.A.M.); Safa_an78@yahoo.com (S.A.E.-K.M.H.) \\ 2 Forestry and Wood Technology Department, Faculty of Agriculture (EL-Shatby), Alexandria University, \\ Alexandria 21545, Egypt \\ 3 Botany and Microbiology Department, College of Science, King Saud University, P.O. Box 2455, \\ Riyadh 11451, Saudi Arabia; hayhassan@ksu.edu.sa \\ 4 Timber Trees Research Department, Sabahia Horticulture Research Station, Horticulture Research Institute, \\ Agriculture Research Center, Alexandria 21526, Egypt \\ * Correspondence: mohamed-salem@alexu.edu.eg
}

Received: 13 March 2020; Accepted: 17 April 2020; Published: 22 April 2020

\begin{abstract}
In the present study, Acacia saligna (Labill.) H.L.Wendl. wood blocks with dimensions of $0.5 \times 1 \times 2 \mathrm{~cm}$ were inoculated with five molds (Aspergillus niger, A. flavus, Alternaria tenuissima, Fusarium culmorum, and Trichoderma harzianum) and the changes in the organic acids (oxalic, citric, tartaric, succinic, glutaric, acetic, propionic, and butyric) of powdered wood were analyzed by HPLC. The effects of the five inoculated fungi on the alterations to the wood cell wall ultrastructures were examined by TEM. The wood became more acidic as it was inoculated with the studied fungi. From the HPLC analysis, the oxalic acid ( $293.34 \mu \mathrm{g} / \mathrm{g}$ o.d.) in the A. saligna, A. tenuissima (167.33 $\mu \mathrm{g} / \mathrm{g}$ o.d.), and T. harzianum ( $245.01 \mu \mathrm{g} / \mathrm{g}$ o.d.) wood decreased, but it increased in the $A$. flavus ( $362.08 \mu \mathrm{g} / \mathrm{g}$ o.d.),

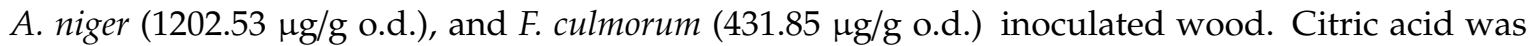
observed in the wood inoculated with A. flavus (110 $\mu \mathrm{g} / \mathrm{g}$ o.d) and A. niger $(2499.63 \mu \mathrm{g} / \mathrm{g}$ o.d). Tartaric (1150.98 $\mu \mathrm{g} / \mathrm{g}$ o.d), acetic $(2.04 \mu \mathrm{g} / \mathrm{g}$ o.d), and propionic $(1.79 \mu \mathrm{g} / \mathrm{g}$ o.d) acids were found in the wood inoculated with $A$. niger. Butyric acid was found in small amounts. A loss of wood substances appeared as the electron-lucent increased in the middle lamella and the layers of the secondary wall. Within the secondary cell wall regions, checks and splits were also noted, which resulted from the effects of the acids on the carbohydrates, according to the fungus type and the acids. In conclusion, increasing the amount of organic acids in the wood samples through inoculation with fungi results in more degradations in the wood, especially in the wood inoculated with A. niger.
\end{abstract}

Keywords: Acacia saligna wood; organic acid; wood cell walls; TEM; HPLC; molds

\section{Introduction}

Wood, as a natural organic material, consists of hemicellulose, cellulose, lignin, and minor amounts of organic extractives, as well as ash as an inorganic mineral [1]. Wood is susceptible and readily degraded by bacteria, fungi, and termites [2-4]. In particular, wood is attacked by fungi when the conditions are suitable, such as a high wood moisture content $(>20 \%)$, the presence of oxygen, and temperatures in the range of $25-40^{\circ} \mathrm{C}$ [5]. Fungi colonize wood by degrading the components of the 
cell wall to form brown, soft, or white rot. Within the cell wall, discrete cavities are formed as soft-rot fungi erode the secondary wall [6]. Sapwood is more susceptible to fungal attack than heartwood, because of the higher concentration of sugars and carbohydrates. Extractives in the heartwood are key in order to make the wood unpalatable to destroying organisms as well as for the prediction of the durability of wood [7]. The $C$ and O element compositions of Acacia saligna wood affected by the fungi Trichoderma harzianum, Alternaria tenuissima, and Fusarium culmorum are decreased compared with the control treatment (unincubated) [8,9].

Cellulase enzymes, such as those derived from the lignocellulolytic fungi of the species T. reesei, Aspergillus niger, A. nidulans, and Penicillium funiculosum, are more selective and competitive to hydrolyze cellulose into monosaccharides, such as glucose [10]. Hamed and Mansour [11] recommended adding stains of soft-rot fungi (A. niger, P. chrysogenum, and Chaetomium globosum) and surface molds (T. viride and A. alternate) to the wood-destroying fungi classification, in addition to recommending examining their enzymatic systems. In pine and sycamore wood, Hamed [12] proved that $A$. niger produced cavity formation as a decaying type I soft-rot and type II (erosion), while P. chrysogenum caused type II decaying from as wood degradation in the soil. T. viride, as a surface mold, was reported to colonize parenchyma cells and to consume the contents of the nutrients in these cells enzymatically, but not to decompose wood [13].

Fungi play a potent role in wood degradation by increasing the contents of organic acids, and for obtaining nutrients, fungi release extracellular enzymes and acids, and then break down the materials prior to their absorption, releasing microbial degraded materials, gases, or microbial volatile organic compounds (MVOCs) into the environment [14,15]. An increase in organic acids leads to accelerating the degradation of wood. Many fungi, including both the brown and white rot fungi, produce calcium oxalate crystals that adhere to the hyphae $[16,17]$. Oxalate-producing white rot species (Bjerkandera fumosa, C. unicolor, and Phlebia radiate) and a brown rot species (Fomitopsis pinicola) have been studied for calcium oxalate crystal formation [18]. Oxalic acid production by brown-rot decay fungi has eluded many researchers for decades [19-21]. This is then followed by the secretion of hydrolytic enzymes that decompose the polysaccharides' plant cell wall [22,23]. Also, it plays an indirect role in the initiation of the decay process, which reduces the viscosity of the hemicellulose and cellulose [24-26]. Antrodia vaillantii was suggested for the accumulation of significant quantities of oxalic acid when inoculated in copper citrate-treated Southern pine [27]. After a 10-day fermentation process, A. niger and Rhizopus javanicus showed a high oxalic acid production [28].

Acetic acid in wood vinegar has been reported to have fungicidal properties, and can be used as an insect repellent, an odor remover, and as a wood preservative instead of other traditional chemicals $[29,30]$. The $\mathrm{pH}$ decreased from 5.5 to 4.0 during the fermentation process of wheat straw, which indicates the production of organic acids by the white rot fungus Nematoloma frowardii, where malate, fumarate, and oxalate were present at a high level [31]. With specific carbohydrate sources, pollen and algae significantly triggered the exudation of malate with Mucor hiemalis, and pollen and cellulose with oxalate in P. chrysogenum [32].

Adversely, lactic and oxalic acids did not prove any activity against $A$. flavus, A. niger, A. fumigatus, P. glabrum, F. moniliforme, and Cladosporium sphaerospermum, while propionic acid inhibited the growth of A. fumigatus, A. niger, P. glabrum, F. moniliforme, and C. sphaerospermum [33]. Propionic acid exhibited a fungicidal action on A. flavus growth [34]; in addition, acetic, propionic, formic, tartaric, citric, oxalic, and malic acids were more effective than lactic acid on the fungi growth of A. flavus, P. purpurogenum, R. nigricans, and F. oxysporum $[35,36]$.

The appearance of acidic conditions has been reported to enhance the activities of fungal enzymes against wood components $[37,38]$. The present work aims to illustrate the effects of five fungi on the contents of organic acids as well as the type of degradation in the ultrastructure compositions of wood from Acacia saligna. 


\section{Materials and Methods}

\subsection{Wood Samples and Isolates Tested}

The fungal isolates used in the present study were provided by Dr. Said Behiry, Agricultural Botany Department, Faculty of Agriculture Saba Basha, Alexandria University, and previously had molecular identification as A. niger (acc\#MH355955), A. flavus (acc\#MH355958), and F. culmorum (acc\#MH355954). The fungal isolate T. harzianum was identified by the specific pair of primers THITS-F2 and THITS-R3 and the degenerated primers published by Miyazaki et al. [39], while A. tenuissima isolate was identified upon sequence of the rDNA ITS region amplified by ITS1 and ITS4 primers and H3-1a, H3-1b primers for histone 3 gene amplification [40].

Wood block samples of Acacia saligna (Labill.) H.L.Wendl. were prepared at dimensions of $0.5 \times 1 \times 2 \mathrm{~cm}$ and were inoculated in Petri dishes contain potato dextrose agar (PDA) media with a fungus disc (5-mm diameter) from A. niger, A. flavus, A. tenuissima, F. culmorum, and T. harzianum, separately. The inoculated wood blocks were incubated at $27^{\circ} \mathrm{C}$ and $70 \%$ relative humidity (RH) for three weeks, in order to ensure that the fungi completely colonized each block [8,9,41]. Five wood blocks were used for each fungus. After this period, the Petri dishes were sealed and well-tightened with plastic tape, and were kept in a dry place at the laboratory for four years, from 2014 to 2018. Then, the five wood blocks that were each inoculated with fungi were milled and ground to fine powder using a laboratory Wiley mill (A-47054, Weverk, Karlstad, Sweden) [42]. Then, the powders were screened to obtain samples of a 20 mesh size, which were used for the chemical analysis.

\subsection{Determination of $\mathrm{pH}$ Value}

Approximately $2.5 \mathrm{~g}$ of oven-dried powder of each sample resulted from the inoculation of A. saligna wood with each of A. niger, A. flavus, A. tenuissima, F. culmorum, and T. harzianum, which were weighed and soaked in $25 \mathrm{~mL}$ of distilled water and mixed with a well vortex, and were left at room temperature overnight. After that, the vortex was done and the mixtures were filtered with filter papers. Finally, the $\mathrm{pH}$ Values of the liquid (filtrate) were determined using a $\mathrm{pH}$ meter (BOECO, Hamburg, Germany).

\subsection{Sample Preparation and Extraction Method}

Six samples (five inoculated and one control) with $0.1 \mathrm{~g}$ (20 mesh) of each powder sample were taken for the extraction and analysis [19]. From homogenized sawdust samples, $0.1 \mathrm{~g}$ were extracted with $\mathrm{H}_{2} \mathrm{SO}_{4}(0.1 \mathrm{~N})$ for $1 \mathrm{~h}$ at $25^{\circ} \mathrm{C}$ with rotary mixing, which were then centrifuged $(21,000 \times g, 10 \mathrm{~min})$ and filtered through a $0.45-\mu \mathrm{m}$ filter [43].

\subsection{High-Performance Liquid Chromatography (HPLC)}

The organic acid compositions of the inoculated $A$. saligna wood with each fungus were separated by HPLC Knauer, Berlin, Germany, with a Rezex@ column. The flow rate and UV detector were set at $0.6 \mathrm{~mL} / \mathrm{min}$ and $214 \mathrm{~nm}$, respectively. The temperature of the column oven was kept constant at $65{ }^{\circ} \mathrm{C}$, and the mobile phase was $0.005 \mathrm{M} \mathrm{H}_{2} \mathrm{SO}_{4}$. The data were analyzed using clarityChrom software. The environmental conditions for the separation techniques were set at $26.7^{\circ} \mathrm{C}$ and $\mathrm{RH}$ $32.90 \%$. Standard organic acids of analytical grade of oxalic, citric, tartaric, succinic, glutaric, acetic, propionic, and butyric acids were used for the HPLC analysis.

\subsection{Transmission Electron Microscope (TEM)}

Small sticks of some of the selected wood samples were removed with a scalpel. They were immediately placed in freshly prepared aqueous $1 \% w / v \mathrm{KMnO}_{4}$ and left for $1 \mathrm{~h}$ at room temperature. After continuous washing with distilled water to remove $\mathrm{KMnO}_{4}$, the samples were dehydrated using ethanol and then an ethanol-acetone series (10 steps). They were flat embedded in Spurr's epoxy 
resin. Resin polymerization proceeded at $70{ }^{\circ} \mathrm{C}$ for $24 \mathrm{~h}$, then the samples were sectioned with an ultramicrotome (Reichert FC4). After sectioning, these samples were post-stained using $1 \% w / v \mathrm{KMnO}_{4}$. Observation was done with a transmission electron microscope (Zeiss E-M10) at 60-80 kv.

\section{Results and Discussion}

\section{1. $p H$ Value}

Table 1 presents the $\mathrm{pH}$ values of the powdered wood samples of $A$. saligna after inoculation with each fungus. The wood samples became more acidic after being inoculated with the studied fungi, ranging from 4.39 to 5.81 for inoculated the wood inoculated with A. niger and F. culmorum, respectively, compared with the control treatment ( $\mathrm{pH}$ 6.06). Another study reported that a decrease in the $\mathrm{pH}$ of wood may be indicated at early stages of impregnated and unimpregnated Norway spruce (Picea abies (L). Karst) sapwood decayed by brown-rot fungi (T. versicolor and Schizophyllum commune) [44].

Table 1. Effect of fungi on the $\mathrm{pH}$ values of powdered wood samples of $A$. saligna.

\begin{tabular}{cc}
\hline Treatment & pH Value \\
\hline Control & 6.06 \\
\hline A. flavus & 5.60 \\
\hline A. niger & 4.39 \\
\hline A. tenuissima & 5.24 \\
\hline F. culmorum & 5.81 \\
\hline T. harzianum & 5.40 \\
\hline
\end{tabular}

\subsection{HPLC Analysis of Organic Acids}

The HPLC chromatogram peaks suggest the presence of oxalic, citric, tartaric, succinic, glutaric, acetic, propionic, and butyric acids in the wood samples of $A$. saligna inoculated with $A$. niger, A. flavus, A. tenuissima, F. culmorum, and T. harzianum (shown in Figure 1). The changes in organic acids from the HPLC analysis of the A. saligna wood after inoculation with fungi compared with the control treatment (without fungi) are shown in Table 2. Oxalic acid was present in the wood samples of A. saligna ( $293.34 \mu \mathrm{g} / \mathrm{g}$ o.d.); decreased in the wood incubated with $A$. tenuissima and T. harzianum; and increased in wood incubated with A. flavus, A. niger, and F. culmorum. The wood samples inoculated with $A$. flavus and $A$. niger showed the highest amounts of citric acid.

Tartaric acid was found in high amounts (1150.98 $\mu \mathrm{g} / \mathrm{g}$ o.d. sample), while acetic and propionic acids were observed in low amounts, only in the wood samples inoculated with $A$. niger. Succinic acid was found only after the wood was inoculated with A. niger and A. tenuissima. Glutaric acid was found in the wood samples that were inoculated with A. flavus, A. niger, F. culmorum, and T. harzianum, but not detected in the wood inoculated with $A$. tenuissima or in the control treatment.

Butyric acid was found in small amounts in the control treatment, but the values increased in the wood inoculated with A. flavus, A. niger, and T. harzianum, and decreased in the wood sample inoculated with $A$. tenuissima.

The wood sample inoculated with $A$. niger showed the presence of all of the organic acids, with high amounts of oxalic, citric, tartaric, succinic, and glutaric acids. Oxalic acid was found, in either high or low amounts, in all of the samples inoculated with fungi, suggesting that this acid is dominant in A. saligna wood. During the alkaline pulping of Acacia, a significant amount of oxalate was formed and released from the wood, where a higher hydroxide concentration led to a higher oxalate content in the black liquor during the early stages of Acacia wood cooking [45].

During fermentation, fungi produce not only oxalic acid, but also other organic acids, such as citric, gluconic, glucuronic, and malic, depending on the operating conditions [28,46-48]. Oxalic acid 
is involved in wood-rotting fungi (brown- and white-rot fungi) mediated processes, including lignocellulose degradation and the breakdown of xenobiotic pollutants [18,49]. Oxaloacetase and glyoxylate oxidase are two oxalate enzymes produced from wood-rotting fungi [50]. Brown-rot fungi produce large amounts of oxalic acid [49]. The synthesis of oxalate is an energy efficient process, and the excreted oxalic acid, as a by-product of sugar oxidation, proves that oxaloacetic acid can be formed through the carboxylation of pyruvate in the cytoplasm [51].

After two weeks of exposure to A. vaillantii, a significant reduction in the $\mathrm{pH}$ was observed [44]. The reason for this drop may be from the oxalic acid produced by brown-rot fungi [52]. Oxalic acid has an important role in the first, pre-visual, non-enzymatic stages of decay $[53,54]$. At a pH higher than 6 , A. niger effectively secretes oxalic acid, while if the fermentation is carried out under acidic conditions ( $\mathrm{pH} 2$ to 3), the main product is usually citric acid [46,47].

It was reported that $A$. niger is an established organism for the industrial production of citric and oxalic acids, as well as the enzymes gluconic acid and ethanol [55-57]. In low concentrations, A. niger strains are known to produce succinic acid [58], as well as a minor co-product production of citric acid [59]. Succinic acid was directly produced from minimally pretreated lignocellulosic biomass with employing a mixed lignocellulolytic and acidogenic A. niger and T. reesei co-culture [60].

At elevated carbohydrate concentrations, organic acids of malic, citric, succinic, and fumaric acids were identified mostly in liquid cultures, while oxalic acid was dominant among the acids produced by A. niger, and its production was decreased by P. citrinum at high carbohydrate concentrations [61]. Carbohydrates, especially fructose, are mainly involved in biosynthetic processes [62], which is suitable for the formation of organic acids in the Krebs cycle, such as fumaric, malic, and succinic acid synthesis. T. harzianum was reported to decompose cellulose and other carbohydrates to glucose within the parenchyma cells and the pits, while it lacks ligninolytic activity $[63,64]$. Another study showed that no cell wall degradation signs appeared in the wood samples inoculated with $T$. harzianum $[8,65]$.

Table 2. High-performance liquid chromatography (HPLC) analysis of wood organic acids as affected by growing five fungi.

\begin{tabular}{|c|c|c|c|c|c|c|}
\hline \multirow{2}{*}{ Organic Acid } & \multicolumn{6}{|c|}{ Amount ( $\mu \mathrm{g} / \mathrm{g}$ o.d. Sample) } \\
\hline & Control & A. flavus & A. niger & A. tenuissima & F. culmorum & T. harzianum \\
\hline Oxalic acid & 293.34 & 362.08 & 1202.53 & 167.33 & 431.85 & 245.01 \\
\hline Citric acid & ND & 110 & 2499.63 & ND & ND & ND \\
\hline Tartaric acid & ND & ND & 1150.98 & ND & ND & ND \\
\hline Succinic acid & ND & ND & 2096.28 & 32.33 & ND & ND \\
\hline Glutaric acid & ND & 23.34 & 2497.59 & ND & 27.88 & 64.46 \\
\hline Acetic acid & ND & ND & 2.04 & ND & ND & ND \\
\hline Propionic acid & ND & ND & 1.79 & ND & ND & ND \\
\hline Butyric acid & 0.24 & 0.64 & 1.99 & 0.04 & ND & 0.35 \\
\hline
\end{tabular}



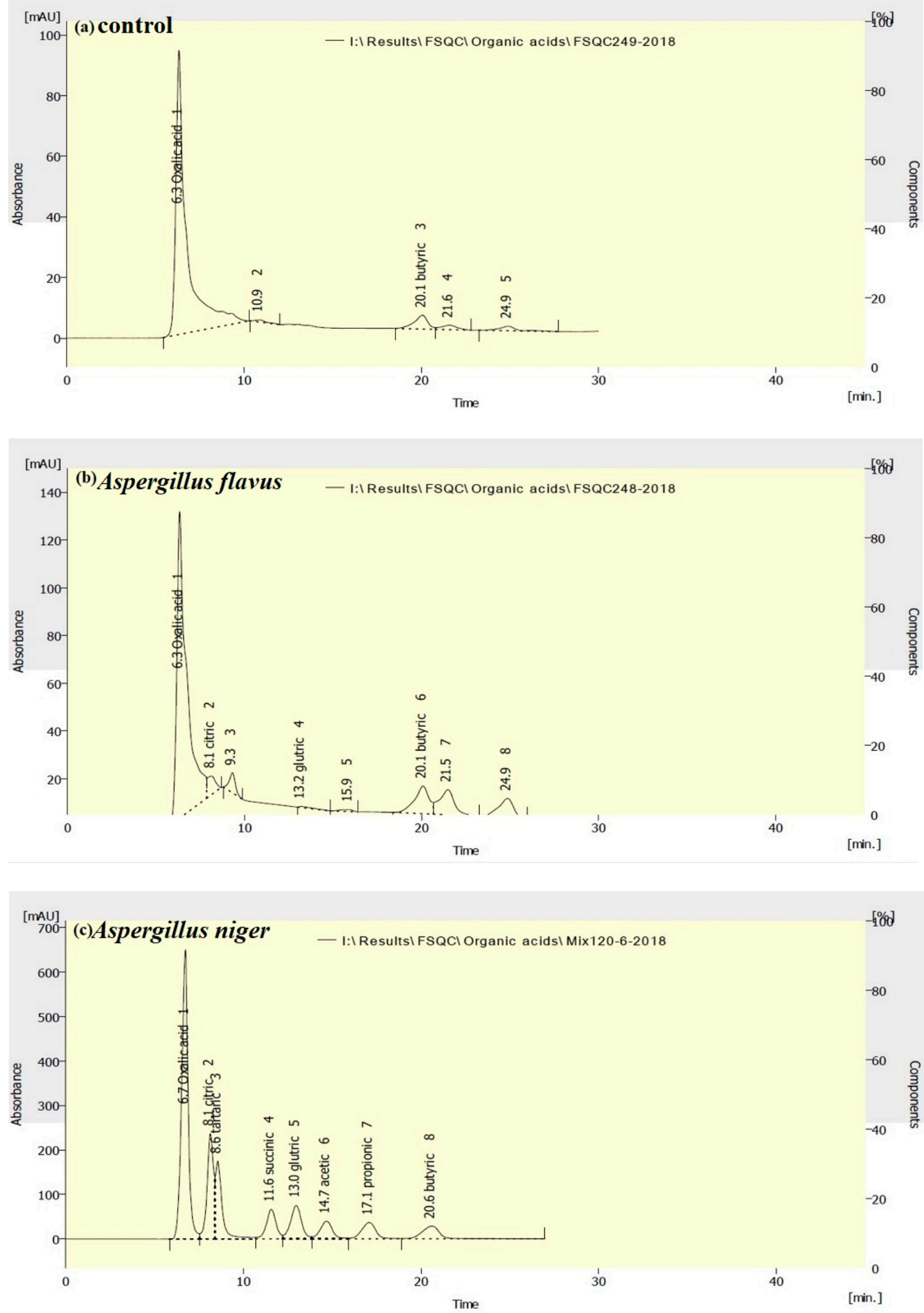

- - \%

$-80$

Figure 1. Cont. 

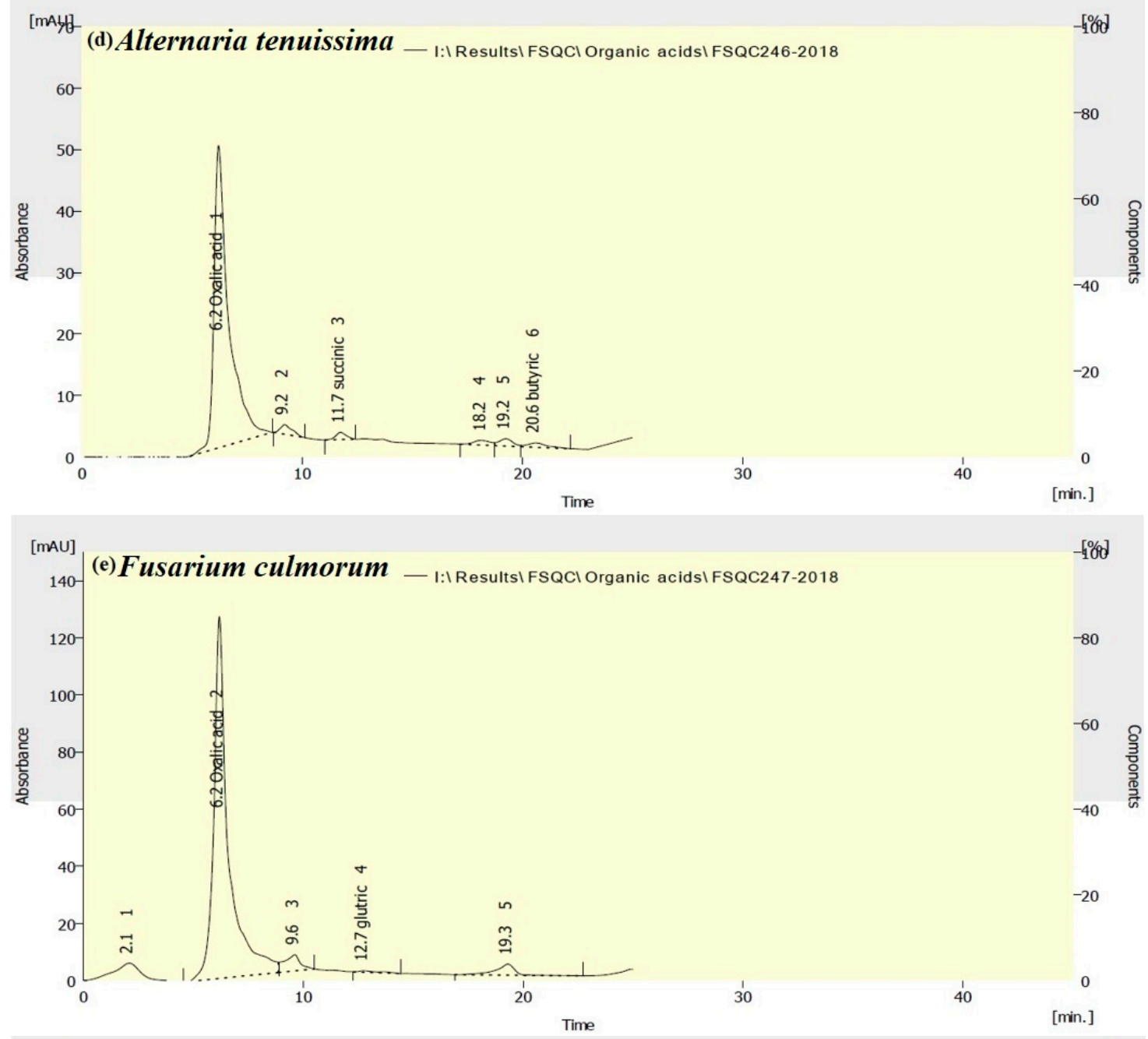

$-1 \%$

$-80$
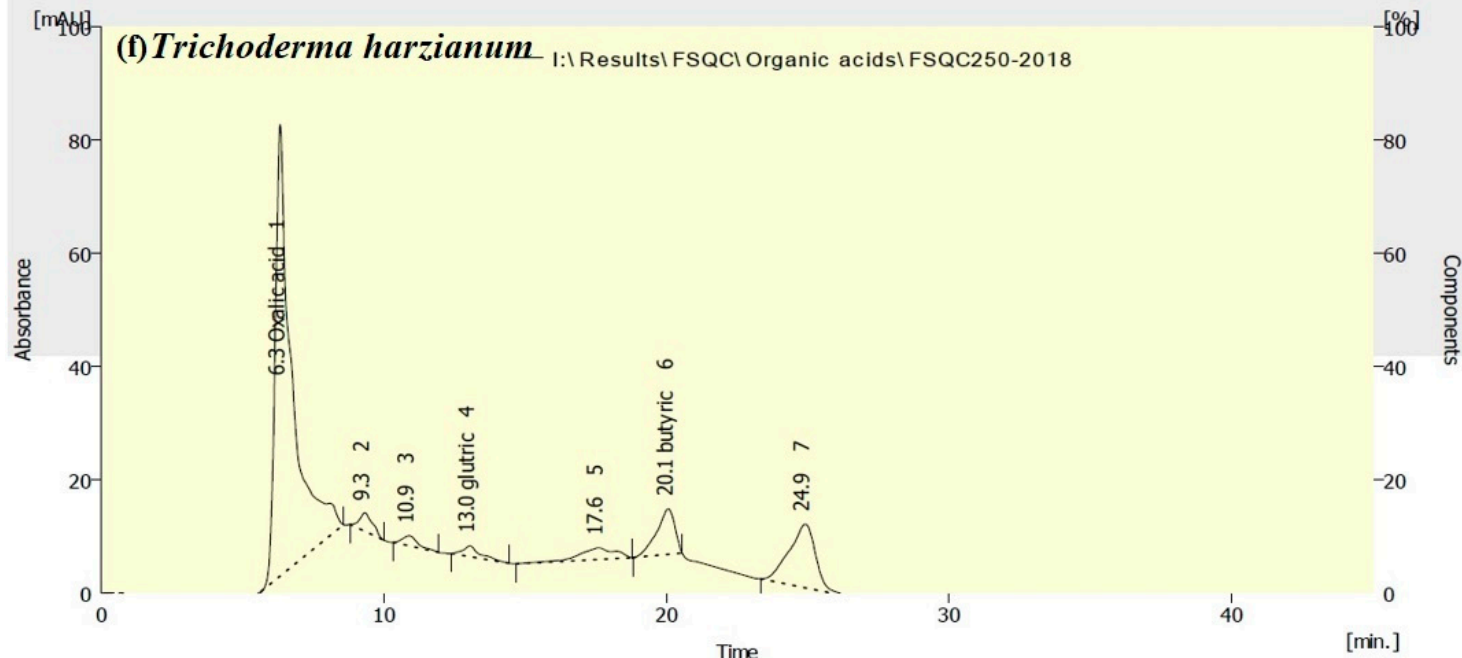

Figure 1. HPLC chromatograms of changes in the organic acids of $A$. saligna wood inoculated with (a) the control, (b) A. flavus, (c) A. niger, (d) A. tenuissima, (e) F. culmorum, and (f) T. harzianum. 


\subsection{TEM Examination of the Inoculcated A. saligna Wood with Fungi}

TEM studies show that erosion and losing parts of the secondary wall occurred. The middle lamella remained intact in the majority of samples. The formation of cavities in the cell walls was the dominant feature. The formation of cavities within the $S_{1}, S_{2}$, or $S_{3}$ layers and erosion depend on the fungus type [11,12].

As it can be seen from the TEM micrographs, the most affected samples were those infested with A. niger, where the effect of the fungus on the wood cells appeared in the presence of soft-rot cavities, especially within the secondary cell walls of the $S_{1}$ and $S_{3}$ layers (Figure $2 b-e$ ) compared to control (Figure 2a). Soft-rot decay type II (erosion) was obvious in the samples infested with $A$. flavus, starting from the $S_{2}$ layer and extending to the $S_{1}$ layer. An increase in the electron-lucent appearance of some regions in the middle lamella and secondary wall layers suggests a loss of wood substance (Figure 3a,c). In addition, checks and splits were frequently noted within the secondary cell wall regions (Figure $2 b$ ).

The wood samples infected with F. culmorum showed general laceration in the wood tissue because of sectioning, which indicates the weakness of the sample. In addition, soft-rot decay type II (erosion) starting from the $S_{2}$ layer and extending to the $S_{1}$ layer was apparent (Figure 4). A. tenuissima caused ultrastructure alterations in the wood samples similar to soft-rot fungi, regarding cavities (soft-rot decay type I) within the $S_{3}$ layer (Figure 5). Moreover, T. harzianum caused two types of soft-rot decay in wood samples, namely: cavities within the $S_{3}$ and $S_{1}$ layers and erosion within the $S_{3}$ layer (Figure 6). These results, regarding the patterns and mechanisms of degradation, are consistent with previous studies [11,12].

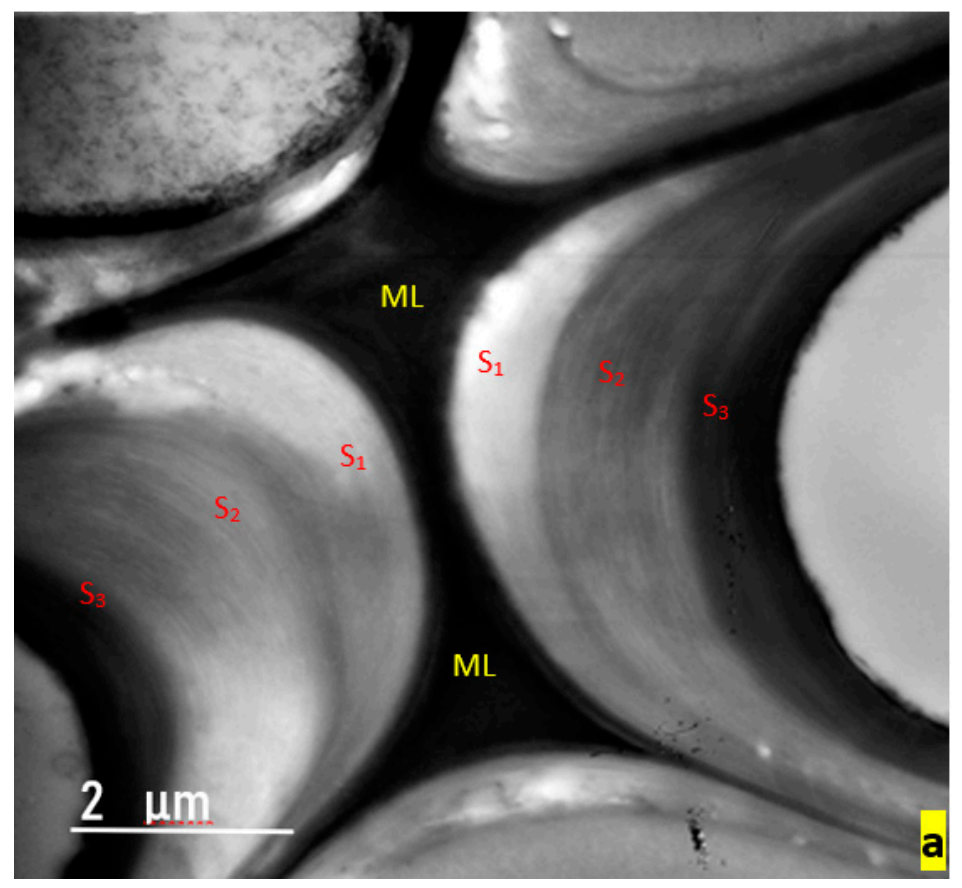

Figure 2. Cont. 

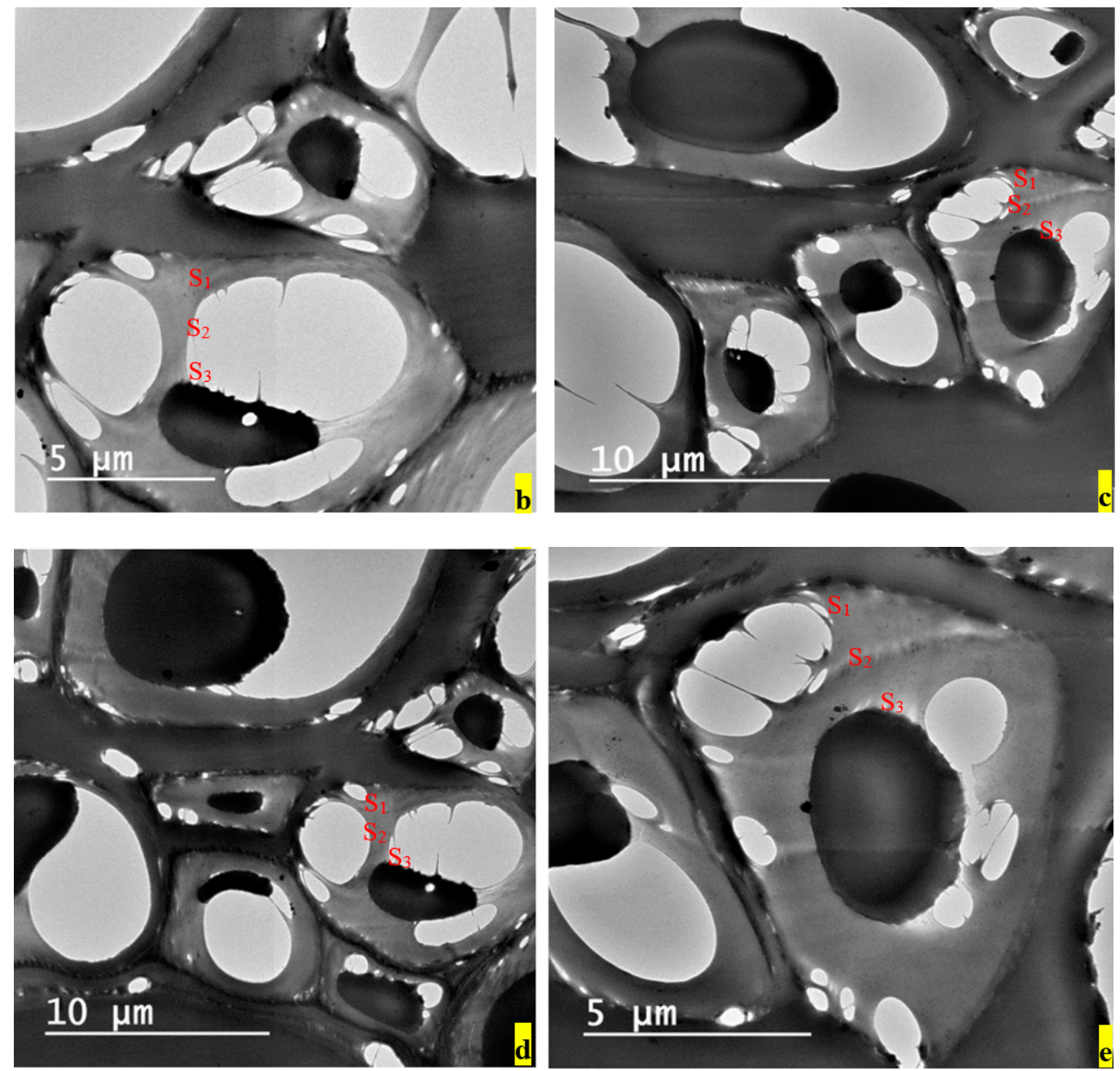

Figure 2. Transmission electron microscope (TEM) photos of control treatment (a) and wood samples infected with A. niger (b-e), showing the effect of the fungus on the wood cells, which appears in the presence of soft-rot cavities, especially within the $S_{1}$ and $S_{3}$ layers. ML-middle lamella; $S_{1}, S_{2}$, $\mathrm{S}_{3}$ - secondary cell wall layers of wood.
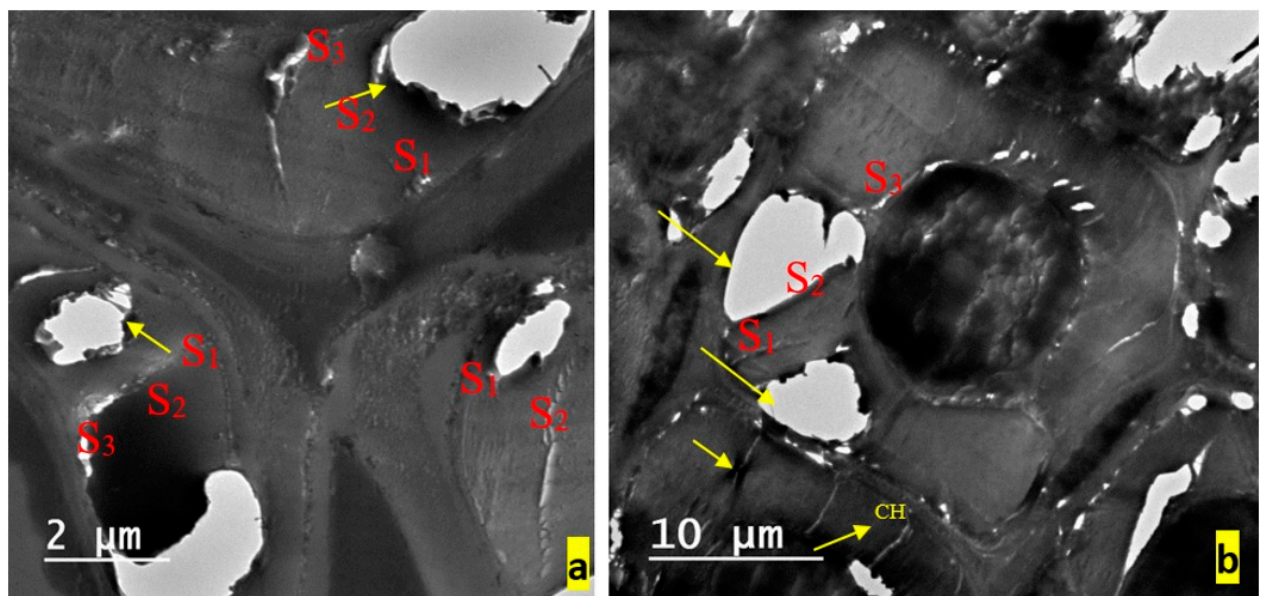

Figure 3. Cont. 


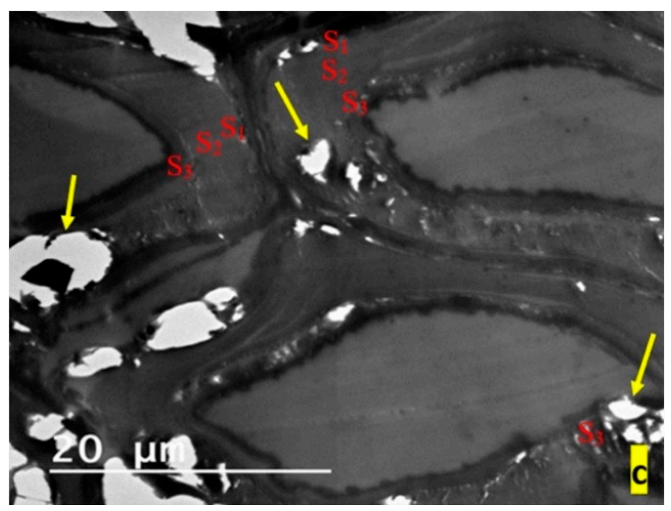

Figure 3. TEM photos of wood samples infected with A. flavus, showing soft-rot decay type II (erosion), starting from the $S_{2}$ layer and extending to the $S_{1}$ layer. Increasing the electron-lucent appearance of some regions in middle lamella and secondary wall layers suggests a loss of wood substance (a,c). In addition, checks $(\mathrm{CH})$ and splits are frequently noted within the secondary cell wall regions (b).
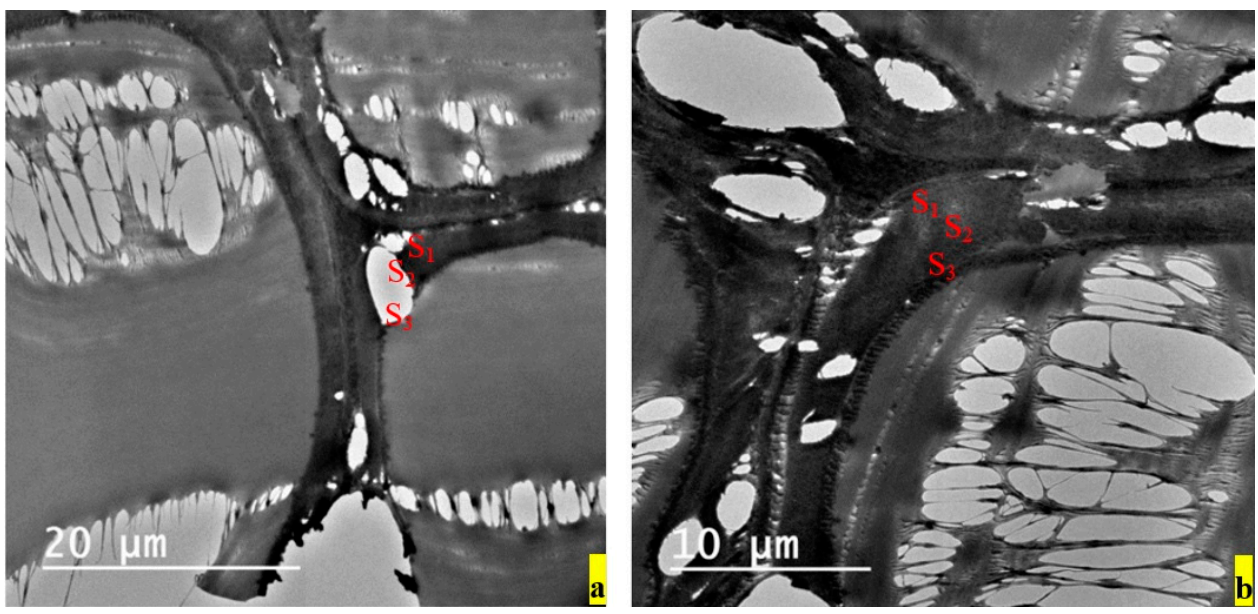

Figure 4. TEM photos $(\mathbf{a}, \mathbf{b})$ of wood samples infected with Fusarium showing soft-rot decay type II (erosion), starting from the $S_{2}$ layer and extending to the $S_{1}$ layer. The general apparent lacerations result from sectioning.
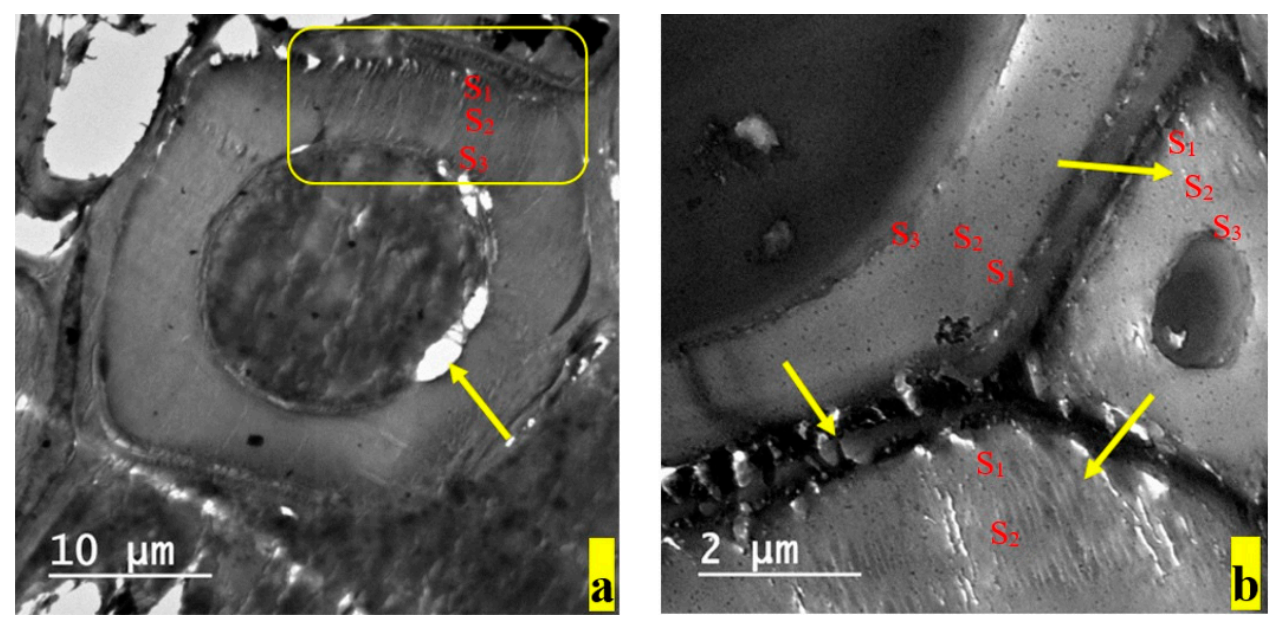

Figure 5. TEM photos of wood samples infected with A. tenuissima, showing cavities within the $\mathrm{S}_{3}$ layer similar to soft-rot decay type I (a). Furthermore, checks and fissures (shown by arrows), are found within the $S_{1}$ and $S_{2}$ layers, with extensive erosion of the middle lamellae region (b). 

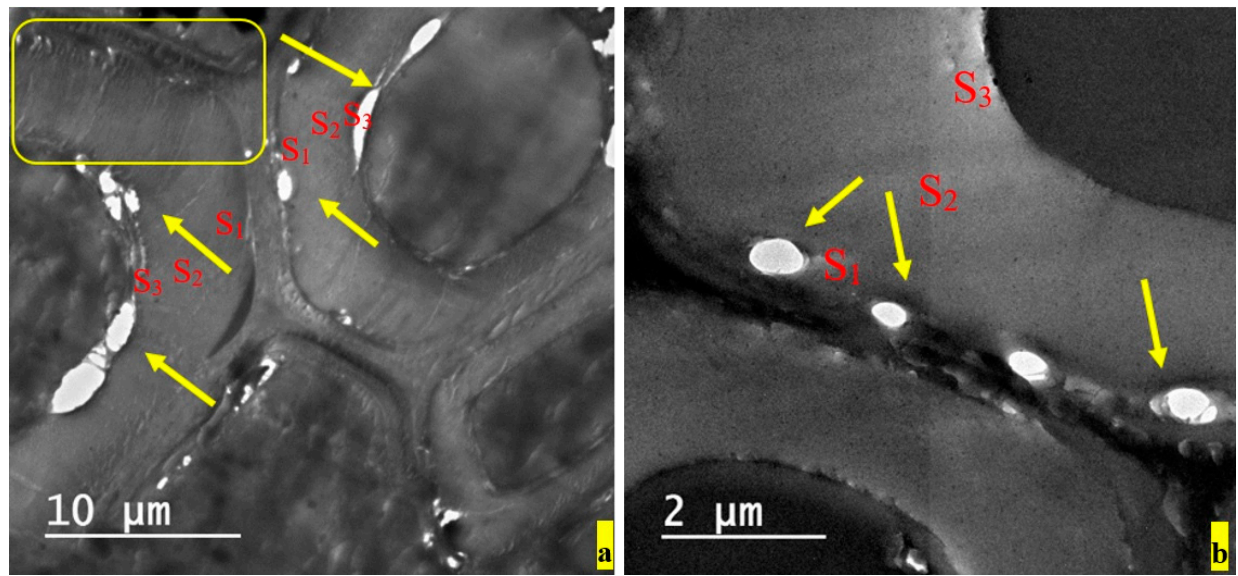

Figure 6. TEM photos $(\mathbf{a}, \mathbf{b})$ of wood samples infected with $T$. harzianum, showing cavities within the $\mathrm{S}_{3}$ and $S_{1}$ layers, similar to soft-rot decay type $I$, and erosion within $S_{3}$ (soft-rot decay type II). In addition, checks can be seen within the $\mathrm{S}_{2}$ layer.

\section{Conclusions}

In this study, A. niger, A. flavus, A. tenuissima, F. culmorum, and T. harzianum were bio-assayed for their effects on organic acids and ultrastructure alterations in wood in the cell walls of $A$. saligna. These measurements were done using HPLC and TEM techniques. An increase in the electron-lucent appearance of some regions in the middle lamella and secondary wall layers suggests a loss of wood substance; in addition, checks and splits were frequently noted within the secondary cell wall regions, indicating the effect of acids on the carbohydrates (cellulose and hemicellulose), according to the fungus type and the acids. Although the wood samples were inoculated with different fungi for the same period of time, the effect of these fungi on the wood acidity differs according to the fungus type. A. niger severely increased the samples' acidity, leading to the destruction of the carbohydrate-rich layers in the wood cells, resulting in more degradations of the cell wall ultrastructure. A. tenuissima and T. harzianum have almost the same effect on wood acidity and wood cells. What is more, the wood samples inoculated with F. culmorum and A. flavus have a lower $\mathrm{pH}$ Value compared with the other fungi, but their content of oxalic acid and the degradation in their structure was bigger than those inoculated with A. tenuissima and T. harzianum.

Author Contributions: Conceptualization, M.M.A.M. and S.A.E.-K.M.H.; methodology, M.M.A.M., S.A.E.-K.M.H., and M.Z.M.S.; software, M.Z.M.S.; validation, M.M.A.M., S.A.E.-K.M.H., M.Z.M.S., and H.M.A.; formal analysis, M.M.A.M., S.A.E.-K.M.H., and M.Z.M.S.; investigation, M.M.A.M., S.A.E.-K.M.H., M.Z.M.S., and H.M.A.; resources, M.M.A.M. and S.A.E.-K.M.H.; data curation, M.M.A.M., S.A.E.-K.M.H., M.Z.M.S., and H.M.A.; writing (original draft preparation), M.M.A.M., S.A.E.-K.M.H., and M.Z.M.S.; writing (review and editing), M.M.A.M., S.A.E.-K.M.H., M.Z.M.S., and H.M.A.; visualization, M.Z.M.S.; supervision, M.Z.M.S.; project administration, H.M.A.; funding acquisition, H.M.A. All authors have read and agreed to the published version of the manuscript.

Funding: This research was funded by the Researchers Supporting Project (RSP-2019/123) from King Saud University, Riyadh, Saudi Arabia.

Acknowledgments: Researchers Supporting Project number (RSP-2019/123) King Saud University, Riyadh, Saudi Arabia.

Conflicts of Interest: The authors declare no conflict of interest.

\section{References}

1. Pettersen, R.C. The chemical composition of wood. In The Chemistry of Wood, Advances in Chemistry Series 207; Rowell, R.M., Ed.; American Chemical Society: Washington, DC, USA, 1984; pp. 57-126.

2. Walker, J.C.F. Primary Wood Processing. In Principles and Practice, 1st ed.; Chapman and Hall: London, UK, $1993 ;$ p. 285. 
3. Schultz, T.P.; Nicholas, D.D. Development of Environmentally-benign Wood Preservatives based on the Combination of Organic Biocides with Antioxidants and Metal chelators. Phytochemistry 2002, 61, 555-560. [CrossRef]

4. Syofuna, A.; Banana, A.Y.; Nakabonge, G. Efficiency of natural wood extractives as wood preservatives against termite attack. Maderas. Ciencia Tecnol. 2012, 14, 155-163. [CrossRef]

5. Woodard, A.C.; Milner, H.R. Sustainability of Construction Materials, 2nd ed.; Woodhead Publishing: Cambridge, UK, 2016.

6. Blanchette, R.A.; Obst, J.R.; Hedges, J.I.; Weliky, K. Resistance of hardwood vessels to degradation by white rot Basidiomycetes. Canad. J. Bot. 1988, 66, 1841-1847. [CrossRef]

7. Hinterstoisser, B.; Steke, B.; Schwanninger, M. Wood: Raw material- material-Source of Energy for the future. Lignovisionen 2000, 2, 29-36.

8. Mansour, M.M.A.; Salem, M.Z.M. Evaluation of wood treated with some natural extracts and Paraloid B-72 against the fungus Trichoderma harzianum: Wood elemental composition, in-vitro and application evidence. Int. Biodeter. Biodegr. 2015, 100, 62-69. [CrossRef]

9. Mansour, M.M.A.; Abdel-Megeed, A.; Nasser, R.A.; Salem, M.Z.M. Comparative evaluation of some woody trees methanolic extracts and Paraloid B-72 against phytopathogenic mold fungi Alternaria tenuissima and Fusarium culmorum. BioResources 2015, 10, 2570-2584. [CrossRef]

10. Yang, B.; Dai, Z.; Ding, S.; Wyman, C.E. Enzymatic hydrolysis of cellulosic biomass. Biofuels 2011, 2, 421-450. [CrossRef]

11. Hamed, S.A.M.; Mansour, M.M. Comparative study on micromorphological changes in wood due to soft-rot fungi and surface mold. Sci. Cult. 2018, 4, 35-41.

12. Hamed, S.A.M. In-vitro studies on wood degradation in soil by soft-rot fungi: Aspergillus niger and Penicillium chrysogenum. Int. Biodeter. Biodegr. 2013, 78, 98-102. [CrossRef]

13. Unger, A.; Schniewind, A.P.; Unger, W. Conservation of Wood Artifacts; Springer: Berlin/Heidelberg, Germany, 2001.

14. Górny, R.L.; Reponen, T.; Willeke, K.; Robine, E.; Boissier, M.; Grinshpun, S.A. Release of fungal fragments from moldy surfaces. Appl. Environ. Microbiol. 2002, 68, 3522-3531.

15. Madsen, A.M.; Kruse, P.; Schneider, T. Characterization of microbial particle release from biomass and building material surfaces for inhalation exposure risk assessment. Ann. Occup. Hyg. 2006, 50, 175-187. [PubMed]

16. Connolly, J.H.; Jellison, J. Calcium translocation, calcium oxalate accumulation, and hyphal sheath morphology in the white-rot fungus Resinicium Bicolor. Can. J. Bot. 1995, 73, 927-936. [CrossRef]

17. Dutton, M.V.; Evans, C.S. Oxalate production by fungi: Its role in pathogenicity and ecology in the soil environment. Can. J. Microbiol. 1996, 42, 881-895. [CrossRef]

18. Jarosz-Wilkolazka, A.; Gadd, G.M. Oxalate production by wood-rotting fungi growing in toxic metal-amended medium. Chemosphere 2003, 52, 541-547. [CrossRef]

19. Clausen, C.A.; Kenealy, W.; Lebow, P.K. Oxalate analysis methodology for decayed wood. Int. Biodeter. Biodegr. 2008, 62, 372-375. [CrossRef]

20. Eastwood, D.C.; Floudas, D.; Binder, M.; Majcherczyk, A.; Schneider, P.; Aerts, A.; Asiegbu, F.O.; Baker, S.E.; Barry, K.; Bendiksby, M.; et al. The plant cell wall-decomposing machinery underlies the functional diversity of forest fungi. Science 2011, 333, 762-765. [CrossRef] [PubMed]

21. Shah, F.; Mali, T.; Lundell, T.K. Polyporales Brown Rot Species Fomitopsis pinicola: Enzyme Activity Profiles, Oxalic Acid Production, and $\mathrm{Fe}^{3+}$-Reducing Metabolite Secretion. Appl. Environ. Microbiol. 2018, 84, e02662-17. [CrossRef]

22. Zhang, J.; Presley, G.N.; Hammel, K.E.; Ryu, J.S.; Menke, J.R.; Figueroa, M.; Hu, D.; Orr, G.; Schilling, J.S. Localizing gene regulation reveals a staggered wood decay mechanism for the brown rot fungus Postia placenta. Proc. Nat. Acad. Sci. USA 2016, 113, 10968-10973. [CrossRef]

23. Presley, G.N.; Schilling, J. Distinct growth and secretome strategies for two taxonomically divergent brown rot fungi. Appl. Environ. Microbiol. 2017, 83, e02987. [CrossRef]

24. Bech-Anderson, J. Production, Function, and Neutralization of Acid Produced by the Dry Rot Fungus and Other Brown-Rot Fungi; International Research Group on Wood Preservation, IRG/WP/1330: Stockholm, Sweden, 1987; p. 16. 
25. Green, F.; Larsen, M.J.; Winandy, J.E.; Highley, T.L. Role of oxalic acid in incipient brown-rot decay. Mater. Org. 1991, 26, 191-213.

26. Shimada, M.; Akamatsu, Y.; Ohta, A.; Takahashi, M. Biochemical Relationships between Biodegradation of Cellulose and Formation of Oxalic Acid in Brown-Rot Wood Decay; International Research Group on Wood Preservation, IRG/WP/ 1472: Stockholm, Sweden, 1991; p. 3.

27. Clausen, C.A.; Green III, F. Oxalic acid overproduction by copper-tolerant brown-rot basidiomycetes on southern yellow pine treated with copper-based preservatives. Int. Biodeter. Biodegr. 2003, 51, 138-144. [CrossRef]

28. Kartal, S.N.; Katsumata, N.; Imamura, Y. Removal of copper, chromium, and arsenic from CCA-treated wood by organic acids released by mold and staining fungi. Forest Prod. J. 2006, 56, 33-37.

29. Oramahi, H.A.; Yoshimura, T. Antifungal and antitermitic activities of wood vinegar from Vitex pubescens Vahl. Wood Sci. 2013, 59, 344-350. [CrossRef]

30. Chungsiriporn, J.; Pongyeela, P.; Iewkittayakorn, J. Use of wood vinegar as fungus and malodor retarding agent for natural rubber products. Songklanakarin J. Sci. Technol. 2018, 40, 87-92.

31. Hofrichter, M.; Vares, T.; Kalsi, M.; Galkin, S.; Scheibner, K.; Fritsche, W.; Hatakka, A. Production of manganese peroxidase and organic acids and mineralization of 14C-labelled lignin (14C-DHP) during solid-state fermentation of wheat straw with the white rot fungus Nematoloma Frowardii. Appl. Environ. Microbiol. 1999, 65, 1864-1870. [CrossRef] [PubMed]

32. Brunner, I.; Goren, A.; Schlumpf, A. Patterns of organic acids exuded by pioneering fungi from a glacier forefield are affected by carbohydrate sources. Environ. Res. Lett. 2014, 9, 025002. [CrossRef]

33. Conkova, E.; Para, L.; Kocisova, A. Inhibition of growth of microscopic fungi with organic acids. Vet. Med. 1993, 38, 723-727.

34. Lin, C.D.; Chen, T.C. Relative antifungal efficacies of phosphoric acid and other compounds on fungi isolated from poultry feed. Animal Feed Sci. Technol. 1995, 54, 217-226. [CrossRef]

35. Pelaez, A.M.L.; Catano, C.A.S.; Yepes, E.A.Q.; Villarroel, R.R.G.; Antoni, G.L.D.; Giannuzzi, L. Inhibitory activity of lactic and acetic acid on Aspergillus flavus growth for food preservation. Food Cont. 2012, 24, 177-183. [CrossRef]

36. Hassan, R.; El-Kadi, S.; Sand, M. Effect of some organic acids on some fungal growth and their toxins production. Inter. J. Adv. Biol. 2015, 2, 1-11. [CrossRef]

37. Hatakka, A.; Hammel, K.E. Fungal biodegradation of lignocelluloses. In Industrial Applications; Springer: Berlin/Heidelberg, Germany, 2011.

38. Lundell, T.K.; Mäkelä, M.R.; de Vries, R.P.; Hildén, K.S. Genomics, lifestyles and future prospects of wood-decay and litter-decomposing basidiomycota. In Advances in Botanical Research; Academic Press: Cambridge, MA, USA, 2014.

39. Miyazaki, K.; Tsuchiya, Y.; Okuda, T. Specific PCR assays for the detection of Trichoderma harzianum causing green mold disease during mushroom cultivation. Mycoscience 2009, 50, 94-99. [CrossRef]

40. Wang, T.; Zhao, J.; Ma, G.; Bao, S.; Wu, X. Leaf blight of sunflower caused by Alternaria tenuissima and A. alternata in Beijing, China. Canad. J. Plant Pathol. 2019, 41, 372-378. [CrossRef]

41. Salem, M.Z.M.; Zidan, Y.E.; El Hadidi, N.M.N.; Mansour, M.M.A.; Abo Elgat, W.A.A. Evaluation of usage three natural extracts applied to three commercial wood species against five common molds. Int. Biodeter. Biodegr. 2016, 110, 206-226. [CrossRef]

42. Salem, M.Z.M.; Abo Elgat, W.A.A.; Taha, A.S.; Fares, Y.G.; Ali, H.M. Impact of Three Natural Oily Extracts as Pulp Additives on the Mechanical, Optical, and Antifungal Properties of Paper Sheets Made from Eucalyptus camaldulensis and Meryta sinclairii Wood Branches. Materials 2020, 13, 1292. [CrossRef]

43. Kenealy, W.; Horn, E.; Davis, M.; Swaney, R.; Houtman, C. Vapor-phase diethyl oxalate pretreatment of wood chips: Part 2. Release of hemicellulosic carbohydrates. Holzforschung 2007, 61, 230-235. [CrossRef]

44. Humar, M.; Petric, M.; Pohleven, F. Changes of the $\mathrm{pH}$ value of impregnated wood during exposure to wood-rotting fungi. Holz Roh-und Werksloff 2001, 59, 288-293. [CrossRef]

45. Li, H.; Chai, X.-S.; DeMartini, N. Oxalate Release and Formation during Alkaline Pulping. J. Wood Chem. Technol. 2012, 32, 187-197. [CrossRef]

46. Camaselle, C.; Bohlmann, J.T.; Núñez, M.J.; Lema, J.M. Oxalic acid production by Aspergillus niger. Bioprocess Eng. 1998, 19, 245-252. [CrossRef] 
47. Kartal, S.N.; Kakitani, T.; Imamura, Y. Bioremediation of CCA-C treated wood by Aspergillus niger fermentation. Holz alz Roh Werkstoff 2004, 62, 64-68. [CrossRef]

48. Kartal, S.N.; Imamura, Y. Removal of copper, chromium, and arsenic from CCA-C treated wood: Aspergillus niger fermentation and acid extraction. In Proceedings of the IAWPS 2003 International Conference on Forest Products, Daejeon, South Korea, 21-24 April 2003; pp. 480-485.

49. Shimada, M.; Akamatsu, Y.; Tokimatsu, T.; Mii, K.; Hattori, T. Possible biochemical roles of oxalic acid as a low molecular weight compound involved in brown-rot and white-rot wood decays. J. Biotechnol. 1997, 53, 103-113. [CrossRef]

50. Akamatsu, Y.; Takahasihi, M.; Shimada, M. Cell-free extraction of oxaloacetase from white-rot fungi, including Coriolus versicolor. Wood Res. 1993, 79, 1-6.

51. Kubicek-Pranz, E.M. Nutrition, cellular structure and basic metabolic pathways in Trichoderma and Gliocladium. In Trichoderma and Gliocladium. Basic Biology, Taxonomy and Genetics; Harman, G.E., Kubicek, C.P., Eds.; Taylor \& Francis: London, UK, 1998.

52. Takao, S. Organic acid production by basidiomycetes, I. Screening of acid-producing strains. Appl. Microbiol. 1965, 13, 732-737. [CrossRef] [PubMed]

53. Shimada, M.; Ma, D.B.; Akamatsu, Y.; Hattori, T. A proposed role of oxalic acid in wood decay systems of wood-rolling basidiomycetes. FEMS Microbiol. Rev. 1994, 13, 285-296. [CrossRef]

54. Goodell, B.; Jellison, J.; Liu, J.; Daniel, G.; Paszczynski, A.; Fekete, F.; Krishnamurthy, S.; Jun, L.; Xu, G. Low molecular weight chelators and phenolic compounds isolated from wood decay fungi and their role in the fungal biodegradation of wood. J. Biotechnol. 1997, 53, 133-162. [CrossRef]

55. Papagianni, M. Advances in citric acid fermentation by Aspergillus niger: Biochemical aspects, membrane transport and modeling. Biotechnol. Adv. 2007, 25, 244-263. [CrossRef] [PubMed]

56. Liaud, N.; Giniés, C.; Navarro, D.; Fabre, N.; Crapart, S.; Herpoël- Gimbert, I.; Levasseur, A.; Raouche, S.; Sigoillot, J.-C. Exploring fungal biodiversity: Organic acid production by 66 strains of filamentous fungi. Fungal Biol. Biotechnol. 2014, 1, 1. [CrossRef]

57. Upton, D.J.; McQueen-Mason, S.J.; Wood, A.J. An accurate description of Aspergillus niger organic acid batch fermentation through dynamic metabolic modelling. Biotechnol. Biofuels 2017, 10, 258. [CrossRef]

58. Bercovitz, A.; Peleg, Y.; Battat, E.; Rokem, J.S.; Goldberg, I. Localization of pyruvate carboxylase in organic acid producing Aspergillus strains. Appl. Environ. Microbiol. 1990, 56, 1594-1597. [CrossRef]

59. Ikram-ul, H.; Ali, S.; Qadeer, M.A.; Iqbal, J. Citric acid production by selected mutants of Aspergillus niger from cane molasses. Bioresour. Technol. 2004, 93, 125-130. [CrossRef]

60. Alcantara, J.; Mondala, A.; Hugheym, L.; Shields, S. Direct Succinic Acid Production from Minimally Pretreated Biomass Using Sequential Solid-State and Slurry Fermentation with Mixed Fungal Cultures. Fermentation 2017, 3, 30. [CrossRef]

61. Sazanova, K.V.; Shchiparev, S.M.; Vlasov, D.Y. Formation of organic acids by fungi isolated from the surface of stone monuments. Microbiol. 2014, 83, 516-522. [CrossRef]

62. Jennings, D.H. The Physiology of Fungal Nutrition; Cambridge University Press: Cambridge, UK, 2007.

63. Osono, T.; Takeda, H. Effects of organic chemical quality and mineral nitrogen addition on lignin and holocellulose decomposition of beech leaf litter by Xylaria sp. Eur. J. Soil Biol. 2001, 37, 17-23. [CrossRef]

64. Komon-Zelazowska, M.; Bissett, J.; Zafari, D.; Hatvani, L.; Manczinger, L.; Woo, S.; Lorito, M.; Kredics, L.; Kubicek, C.P.; Druzhinina, I.S. Genetically closely related but oyster mushroom farms worldwide species cause green mold disease in phenotypically divergent Trichoderma. Appl. Environ. Microbiol. 2007, 73, 7415-7426. [CrossRef] [PubMed]

65. Schubert, M.; Fink, S.; Schwarze, F.W.M.R. In vitro screening of an antagonistic Trichoderma strain against wood decay fungi. Arboric. J. 2008, 31, 227-248. [CrossRef]

(C) 2020 by the authors. Licensee MDPI, Basel, Switzerland. This article is an open access article distributed under the terms and conditions of the Creative Commons Attribution (CC BY) license (http://creativecommons.org/licenses/by/4.0/). 